\title{
Sistem Pendukung Keputusan Penerima Beasiswa Dengan Metode Technique For Order Of Preference By Similarity To Ideal Solution (TOPSIS)
}

\author{
Novi Trisna ${ }^{1)}$, Sepsa Nur Rahman', Annisak Izzaty Jamhur ${ }^{3)}$ \\ Universitas Putra Indonesia "YPTK" Padang, Indonesia \\ E-mail: Novi_trisna@upiyptk.ac.id ${ }^{1)}$, Sepsanurrahman@upiyptk.ac.id ${ }^{2)}$, \\ Annisakizzaty@gmail.com ${ }^{3)}$
}

\begin{abstract}
Abstrak
Sistem pendukung keputusan merupakan pasangan intelektual dari sumber daya manusia dengan kemampuan komputer untuk memperbaiki keputusan dalam membantu atau menggantikan secara keseluruhan pengambilan keputusan agar memberikan suatu keputusan yang tepat, efektif dan efisien dalam pengelolaan data penerima besiswa yang benar-benar berhak menerima beasiswa di MTsN Model Padang. Technique for Order of Preference by Similarity to Ideal Solution (TOPSIS) merupakan suatu metode yang memiliki konsep dimana alternatif terpilih yang terbaik tidak hanya memiliki jarak terpendek dari solusi ideal positif, namun juga memiliki jarak terpanjang dari solusi ideal negatif. Kriteria yang digunakan dalam sistem ini beragam, sesuai dengan beasiswa yang disediakan oleh pihak lembaga. Sistem ini mampu memberikan rekomendasi pemberian beasiswa.
\end{abstract}

Kata kunci: Sistem Pendukung Keputusan, TOPSIS, Beasiswa

\begin{abstract}
Decision support system for supporters who provide appropriate, effective and efficient solutions in managing student recipient data who are truly entitled to receive scholarships at MTsN Model Padang. The technique for Preference Order with Similarity to Ideal Solution (TOPSIS) is a method that has the best alternative concept that only has the shortest distance from the positive ideal solution, but also has the longest distance from the negative ideal solution. The criteria used in this system vary, according to scholarships provided by institutions. This system can provide scholarships.
\end{abstract}

Keywords: Decision Support System, TOPSIS, Scholarship

\section{I.PENDAHULUAN}

MTsN Model Padang adalah lembaga pendidikan jenjang Madrasah Tsanawiyah Negeri pada pendidikan formal di Indonesia, setara dengan sekolah menengah pertama negeri, yang pengelolaannya dilakukan oleh
Departemen Agama. Dimana pada setiap tahunnya akan di adakan penyeleksian penerima beasiswa, siswa yang menerima beasiswa tersebut adalah siswa yang memenuhi kriteria tertentu. Dalam pemrosesan penyeleksian penerima beasiswa membutuhkan waktu yang lama, seringkali terjadinya ketidak akuratan 
didalam penentuan siswa yang seharusnya menerima beasiswa terlebih dahalu.

Sistem penunjang keputusan dapat memaximalkan pengambilan keputusan untuk siswa yang berhak menerima beasiswa tersebut dan juga dapat mempermudah petugas didalam memberikan penilaian terhadap calon siswa penerima beasiswa, dengan adanya sistem ini dapat menyeleksi secara detail siswa yang menerima beasiswa adalah siswa yang benar benar patut menerima beasiswa itu dan didalam pemrosesan penyeleksian dapat lebih cepat. Walaupun demikian, hasil dari pengambilan keputusan ini bukan suatu hal yang mutlak karena sistem pendukung keputusan merupakan pemberi alternatif solusi keputusan, sedangkan keputusan mutlak tetap diputuskan oleh pihak pengambil keputusan.

Metode sistem pendukung keputusan yang dapat memilih alternatif kriteria adalah menggunakan metode TOPSIS yang dimana metode ini didasarkan pada konsep alternatif terpilih yang terbaik tidak hanya memiliki jarak terpendek dari solusi ideal positif, namun juga memiliki jarak terpanjang dari solusi ideal negatif.

\section{II.LANDASAN TEORI}

\subsection{Sistem Pendukung Keputusan}

Sistem pendukung keputusan adalah sekumpulan elemen yang saling berhubungan untuk membentuk suatu kesatuan dalam proses pemilihan berbagai alternatif tindakan guna menyelesaikan suatu masalah, sehingga masalah tersebut dapat diselesaikan secara efektif dan efisien. [1]

Keputusan yang di ambil untuk menyelesaikan suatu masalah dapat dilihat dari keterstrukturannya yang bisa di bagi menjadi :

1. Keputusan terstruktur (structured decision) yaitu keputusan yang dilakukan secara berulang-ulang dan bersifat rutin, prosedur pengambilan keputusan sangatlah jelas, keputusan tersebut terutama dilakukan pada menajemen tingkat bawah.

2. Keputusan semiterstruktur (semistructured decision) yaitu keputusan yang memiliki dua sifat, sebagian sifat bisa ditangani oleh komputer dan yang lain tetap harus dilakukan oleh pengambil keputusan, prosedur dalam pengambil keputusan tersebut secara garis besar sudah ada, tetapi ada beberapa hal yang masih memerlukan kebijakan dari pengambil keputusan. Biasanya, keputusan semacam ini di ambil oleh manajer level menengah dalam suatu organisasi.

3. Keputusan tak terstruktur (unstructured decision), yaitu keputusan yang penanganannya rumit karena tidak terjadi beulang-ulang atau tidak selalu terjadi, keputusan tersebut menuntut pengalaman dan berbagai sumber yang bersifat eksternal. Keputusan tersebut umumnya terjadi pada manajemen tingkat atas [2].

\subsection{Beasiswa}

Pada dasarnya, beasiswa adalah penghasilan bagi yang menerimanya.Hal ini sesuai dengan ketentuan pasal 4 ayat (1) UU PPh/2000. Disebutkan pengertian penghasilan adalah tambahan kemampuan ekonomis dengan nama dan dalam bentuk apa pun yang diterima atau diperoleh dari sumber Indonesia atau luar Indonesia yang dapat digunakan untuk konsumsi atau menambah kekayaan Wajib Pajak (WP). Karena beasiswa bisa diartikan 
menambah kemampuan ekonomis bagi penerimanya, berarti beasiswa merupakan penghasilan. [3]

\subsection{Technique For Order Preference By Similarity To Ideal Solution(TOPSIS)}

Technique for Order Performance by Similarity to Ideal Solution (TOPSIS) merupakan salah satu metode dalam pengambilan keputusan, yang mana dalam menghasilkan sebuah keputusan akan memilih alternatif yang tidak hanya paling mendekati solusi ideal positif, akan tetapi juga paling jauh dari solusi ideal negatif [4].

Metode TOPSIS didasarkan pada konsep bahwa alternatif terpilih yang terbaik tidak hanya memiliki jarak terpendek dari solusi ideal positif tetapi juga memiliki jarak terpanjang dari solusi ideal negatif. Tahapan metode Topsis :

1. Membuat matriks keputusan yang ternormalisasi

2. Membuat matriks keputusan yang ternormalisasi terbobot

3. Menentukan matriks solusi ideal positif dan matriks solusi ideal negatif

4. Menentukan jarak antara nilai setiap alternatif dengan matriks solusi ideal positif dan negatif.

5. Menentukan nilai preferensi untuk setiap alternatif [5]

TOPSIS membutuhkan rating kinerja setiap alternatif $\mathrm{Ai}$ pada setiap kriteria $\mathrm{Cj}$ yang ternormalisasi, yaitu:

$r_{i j}=\frac{x_{i j}}{\sqrt{\sum_{i=1}^{m} x_{i j}^{2}}}$ dengan $\mathrm{i}=1,2, \ldots, \mathrm{m} ;$ dan $\mathrm{j}$

$=1,2, \ldots$.
Solusi ideal positif $\mathrm{A}^{+}$dan solusi ideal negatif $\mathrm{A}^{-}$dapat ditentukan berdasarkan rating bobot ternormalisasi $\left(\mathrm{y}_{\mathrm{ij}}\right)$ sebagai:

$$
\begin{aligned}
y_{i j}= & w_{i} r_{i j} \\
\operatorname{dan} \mathrm{j} & =1,2, \ldots, \mathrm{n} . \\
A^{+} & =\left(y_{1}^{+}, y_{2}^{+}, \ldots y_{n}^{+}\right) \\
A^{-} & =\left(y_{1}^{-}, y_{2}^{-}, \ldots y_{n}^{-}\right)
\end{aligned}
$$

Dengan

$$
y_{j}^{+}=
$$

$\left\{\begin{array}{cc}\max y_{i j} ; j i k a \mathrm{j} \text { atribut keuntungan } & i \\ \min y_{i j} ; & j i a k \mathrm{j} \text { adalah atribut biaya } \\ i\end{array}\right.$

$$
y_{j}^{-}=
$$

$\left\{\begin{array}{c}\min y_{i j} ; j i k a \mathrm{j} \text { atribut keuntungan } \\ i \\ \max y_{i j} ; j i a k \mathrm{j} \text { adalah atribut biaya } \\ i\end{array}\right.$

Dimana: $\mathrm{j}=1,2, \ldots \mathrm{n}$.

Sedangkan jarak antara alternatif $A_{i}$ dengan solusi ideal positif dirumuskan sebagai:

$$
\begin{aligned}
& D_{i}^{+}=\sqrt{\sum_{j=1}^{n}\left(y_{i}^{+}-y_{i j}\right)^{2}} ; \quad \mathrm{i}= \\
& 1,2, \ldots \mathrm{m} .
\end{aligned}
$$

Jarak antara alternatif $A_{i}$ dengan solusi ideal negatif dirumuskan sebagai:

$$
D_{i}^{-}=\sqrt{\sum_{j=1}^{n}\left(y_{i j}-y_{i}^{-}\right)^{2}} ; \quad \mathrm{i}=1,2, \ldots \mathrm{m} .
$$

Nilai preferensi untuk setiap alternatif $\left(\mathrm{V}_{\mathrm{i}}\right)$ diberikan sebagai:

$$
V_{i}=\frac{D_{i}^{-}}{D_{i}^{-}+D_{i}^{+}}
$$

Nilai $V_{i}$ yang lebih besar menunjukan bahwa alternatif $A_{i}$ lebih dipilih [6] 


\section{III.Metodologi Penelitian}

Metodologi penelitian sesuai dengan tahapan/kerangka kerja yang akan dilalui pada penelitian ini dapat dilihat pada Gambar 3.1 :

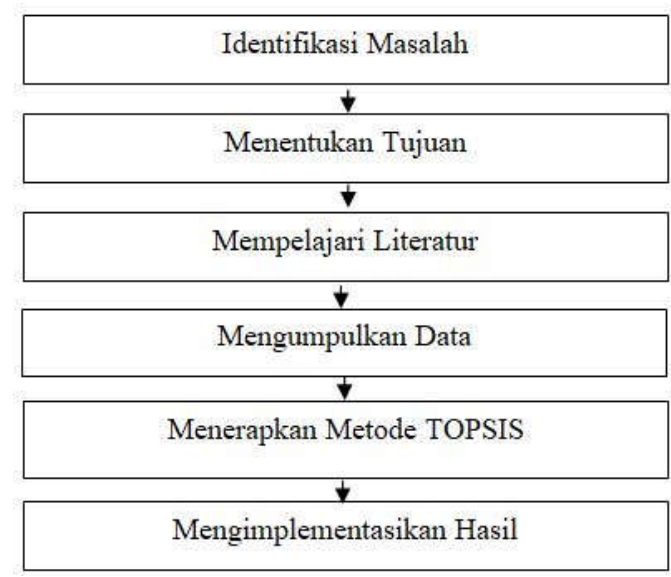

Gambar 3.1 Kerangka Kerja Dalam Penelitian

Berdasarkan kerangka kerja maka masing-masing langkah dapat diuraikan sebagai berikut :

1. Identifikasi Masalah

Identifikasi masalah adalah mengenali masalah apa saja yang akan di pecahkan dalam penelitian ini yang dimana dalam penyeleksian penerima beasiswa di MTsN Model Padang.

2. Menentukan Tujuan

Berdasarkan pemahaman dari masalah, maka ditentukan tujuan yang akan dicapai dari penelitian. Pada tujuan ini ditentukan target yang dicapai, terutama siswa yang menerima beasiswa tersebut adalah siswa yang memenuhi kriteria tertentu.

3. Mempelajari Literatur

Untuk mencapai tujuan yang akan ditentukan, maka perlu dipelajari beberapa literatur-literatur yang digunakan. Kemudian literaturliteratur yang dipelajari tersebut diseleksi untuk dapat ditentukan literatur mana yang akan digunakan dalam penelitian. Melalui studi literatur, dipelajari teori-teori yang berhubungan dengan sistem pendukung keputusan dan metode.Technique for Order Performance by Similarity to Ideal Solution (TOPSIS)

4. Mengumpulkan Data

Untuk mendukung penelitian ini, salah satu penunjangnya adalah Data, dalam pengumpulan data beberapa sample siswa yang akan diseleksi untuk menerima beasiswa.

5. Menerapkan Metode TOPSIS

Menerapkan Metode TOPSIS adalah sebuah metode dengan menentukan kriteria penerima beasiswa yaitu surat keterangan tidak mampu, penghasilan orang tua per bulan dan rekening listrik

6. Mengimplementasi Hasil

Mengimplementasi hasil adalah menerapkan sistem pendukung keputusan dengan metode TOPSIS apakah terdapat kekurangankekurangan pada metode terebut sehingga dapat di ubah lebih menarik untuk kedepannya.

\section{Hasil dan Diskusi}

Pada MTsN Model Padang sample yang digunakan dalam penerima beasiswa dengan metode TOPSIS mengunakan 3 alternatif dan 3 kriteria. Denga kriteria sebagai berikut:

C01 : Surat Keterangan Tidak

Mampu

C02 : Penghasilan Orang Tua

per bulan

C03 : Rekening Listrik

Prosedur perhitungan yang dilakukan adalah : 
1. Memberi Nilai, Membuat Tabel Keputusan

Tabel 3.10 Tabel Keputusan

\begin{tabular}{|c|l|c|c|c|}
\hline NISN & \multicolumn{1}{|c|}{ Nama } & C01 & C02 & C03 \\
\hline 0030718502 & Anisah Yulizar & 4 & 2 & 3 \\
\hline 0024676696 & GenesaPutri Ramadhani & 1 & 5 & 4 \\
\hline 0036419301 & Vony Diva Putri & 4 & 4 & 4 \\
\hline
\end{tabular}

2.Membuat Keputusan Ternormalisasi

Tabel 3.11 Tabel Keputusan Ternormalisasi

\begin{tabular}{|c|c|c|c|}
\hline NISN & C01 & C02 & C03 \\
\hline 0030718502 & 4 & 2 & 3 \\
\hline 0024676696 & 1 & 5 & 4 \\
\hline 0036419301 & 4 & 4 & 4 \\
\hline Hasil pangkat perkriteria & $16+1+16$ & $4+25+16$ & $9+16+16$ \\
\hline Akar hasil pangkat perkriteria & 5.7445 & 6.7082 & 6.4031 \\
\hline
\end{tabular}

Rumus menormalisasikan :

(data)

$\overline{(\text { akar hasil pangkat perkriteria) }}$

Tabel 3.12 Tabel Data Normalisasi

\begin{tabular}{|c|c|c|c|}
\hline NISN & C01 & C02 & C03 \\
\hline 0030718502 & 0.6963 & 0.2981 & 0.4685 \\
\hline 0024676696 & 0.1740 & 0.7453 & 0.6246 \\
\hline 0036419301 & 0.6963 & 0.5962 & 0.6246 \\
\hline
\end{tabular}

3. Memberi Bobot Setiap Kriteria

Sebelum menghitung matrik keputusan normalisasi terbobot, tentukan terlebih dahalu bobot dari masing-masing kriteria. Tingkat kepentingan tiap kriteria dapat dinilai dari range 1 sampai 5, yaitu:

$1:$ Tidak Penting

2 : Tidak terlalu penting

3 : Cukup penting

4 : Penting

5 : Sangat Penting

Tabel 3.13 Tabel Bobot Kriteria

\begin{tabular}{|c|l|c|}
\hline No & \multicolumn{1}{|c|}{ Kriteria } & Bobot \\
\hline 1 & Surat Keterangan Tidak Mampu(C01) & 5 \\
\hline 2 & Penghasilan Orang Tua per bulan(C02) & 4 \\
\hline 3 & Rekening Listrik(C03) & 3 \\
\hline
\end{tabular}

4.Membuat Normalisasi Berbobot

Rumus normalisasi berbobot :

(data normalisasi)

$\times($ bobot kriteria $)$
Tabel 3.14 Tabel Normalisasi Berbobot

\begin{tabular}{|c|c|c|c|}
\hline NISN & C01 & C02 & C03 \\
\hline 0030718502 & $0.6963 \times 5=3.4815$ & $0.2981 \times 4=1.1924$ & $0.4685 \times 3=1.4055$ \\
\hline 0024676696 & $0.1740 \times 5=0.8700$ & $0.7453 \times 4=2.9812$ & $0.6246 \times 3=1.8738$ \\
\hline 0036419301 & $0.6963 \times 5=3.4815$ & $0.5962 \times 4=2,3848$ & $0.6246 \times 3=1.8738$ \\
\hline
\end{tabular}

5.Mencari Max dan Min Dari Normalisasi Berbobot

Tabel 3.15 Tabel Max dan Min

\begin{tabular}{|c|c|c|c|}
\hline NISN & C01 & C02 & C03 \\
\hline 0030718502 & $0.6963 \times 5=3.4815$ & $0.2981 \times 4=1.1924$ & $0.4685 \times 3=1.4055$ \\
\hline 0024676696 & $0.1740 \times 5=0.8700$ & $0.7453 \times 4=2.9812$ & $0.6246 \times 3=1.8738$ \\
\hline 0036419301 & $0.6963 \times 5=3.4815$ & $0.5962 \times 4=2,3848$ & $0.6246 \times 3=1.8738$ \\
\hline MAX & 3.4815 & 2.9812 & 1.8738 \\
\hline MIN & 0.8700 & 1.1924 & 1.4055 \\
\hline
\end{tabular}

Jika kriteria bersifat benefit

(makin besar makin baik) maka

$\mathrm{Y}+=\max$ dan $\mathrm{Y}-=\min$

Jika kriteria bersifat cost (makin kecil makin baik) maka $\mathrm{Y}+=\min$ dan $\mathrm{Y}-=\max$

2. Mencari D+ D- di Setiap Alternatif

Rumus mencari D+

$$
\mathrm{i}=1,2, \ldots \mathrm{m} \text {. }
$$

$$
D_{i}^{+}=\sqrt{\sum_{j=1}^{n}\left(y_{i}^{+}-y_{i j}\right)^{2}} ;
$$

Contoh :

$D \mathrm{l}+=\sqrt{\left(3,4815-3,4815^{2}+\left(2,9812-1,192 y^{2}+\left(1,8738-1405 \mathfrak{F}^{2}\right.\right.\right.}$

Sehingga didapatkan :

Tabel 3.16 Tabel D+

\begin{tabular}{|c|c|}
\hline NISN & $\mathrm{D}+$ \\
\hline 0030718502 & 1.8491 \\
\hline 0024676696 & 2.6115 \\
\hline 0036419301 & 0.5272 \\
\hline
\end{tabular}


Rumus mencari D-

$$
D_{i}^{-}=\sqrt{\sum_{j=1}^{n}\left(y_{i j}-y_{i}^{-}\right)^{2}}
$$

$\mathrm{i}=1,2, \ldots \mathrm{m}$.

Contoh :

$D \mathrm{l}-=\sqrt{\left(3,4815-0,870 \varphi^{2}+\left(1,1924-1,1924^{2}+\left(1,4055-1,4055^{2}\right.\right.\right.}$

Sehingga didapatkan :

Tabel 3.17 Tabel D-

\begin{tabular}{|c|c|}
\hline NISN & D- \\
\hline 0030718502 & 2.6115 \\
\hline 0024676696 & 1.8491 \\
\hline 0036419301 & 2,9087 \\
\hline
\end{tabular}

3. Mencari $\mathrm{V} /$ Hasil

Rumus mencari $\mathrm{V}$ :

$$
V_{i}=\frac{D_{i}^{-}}{D_{i}^{-}+D_{i}^{+}} ;
$$

Hingga didapatkan :

$$
\begin{aligned}
V 1 & =\frac{2,6115}{2,6115+1,8491} \\
V 2 & =\frac{1,8491}{1,8491+2,6115} \\
V 3 & =\frac{2,9087}{2,9087+0,5272}
\end{aligned}
$$

Tabel 3.18 Hasil TOPSIS

\begin{tabular}{|c|c|}
\hline NISN & Nilai \\
\hline 0030718502 & 0,5854 \\
\hline 0024676696 & 0.4146 \\
\hline 0036419301 & 0,8465 \\
\hline
\end{tabular}

Sehingga yang berhak mendapatkan beasiswa diantara tiga sample yaitu siswa yang bernama Vony Diva Putri dengan nomor NISN 0036419301 karena yang diambil dari hasil TOPSIS nilai yang tertinggi.

\section{IV.Kesimpulan}

a. Dengan menganalisa data penerima beasiswa menggunakan metode TOPSIS (Technique for Order Preference by Similarity to Ideal Solution) telah mendapatkan hasil penerima beasiswa dengan nilai tertinggi yang memenuhi kriteria

b. Dengan sistem yang telah dibuat dan sesuai dengan rancangan dapat memudahkan pengguna dalam pemrosesan penyeleksian penerima beasiswa dan didalam pembuatan laporan-laporan yang dibutuhkan untuk pengambilan keputusan.

c. Diharapkan ke depannya penelitian ini dapat dikembangkan lebih baik dan memberikan hasil yang lebih optimal dalam membantu pengambilan keputusan yang tepat dengan memperbanyak kriteria dan jumlah sample.

\section{Referensi}

[1] Saefudin dan Sri Wahyuningsih, "Sistem Pendukung Keputusan Untuk Penilaian Kinerja Pegawai Menggunakan Metode Analytical Hierarchy Process (Ahp) Pada RSUD Serang," Jurnal Sistem Informasi Vol- 1 No.1 2014

[2] Situmorang, Harold,. "Sistem Pendukung Keputusan Pemilihan Calon Peserta Olimpiade Sains Tingkat Kabupaten Langkat Pada Madrasah Aliyah Negeri (Man) 2 Tanjung Pura Dengan menggunakan Metode Simple Additive Weighting (Saw)," Jurnal TIMES , Vol. IV No 2 : 24-30, 2015

[3] Guntur, Nuri Perdana dan Tri Widodo, "Sistem Pendukung Keputusan Pemberian Beasiswa Kepada Peserta Didik Baru Menggunakan Metode TOPSIS," 
Seminar Nasional Teknologi Informasi \& Komunikasi Terapan, 2013

[4] Alit, Putri Widyastuti Santiary, dkk, "Sistem Pendukung Keputusan Penentuan Lokasi Wisata Dengan Metode Topsis," Jurnal Teknologi Informasi dan Ilmu Komputer (JTIIK) , Vol. 5, No. 5, 621-628, 2018.

[5] Sriani dan Raissa Amanda Putri, "Analisa Sistem Pendukung Keputusan Menggunakan Metode Topsis Untuk Sistem Penerimaan Pegawai Pada Sma Al Washliyah Tanjung Morawa," Jurnal Ilmu Komputer dan Informatika Volume: 02, Number : 01, April 2018

[6] Nur, Amelia Fitriana, Harliana, dan Handaru, "Sistem Pendukung Keputusan Untuk Menentukan Prestasi Akademik Siswa dengan Metode TOPSIS," Citec Journal, Vol. 2, No. 2, Februari 2015 - April 2015 